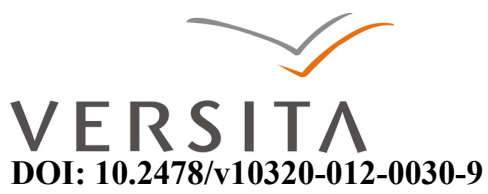

\title{
WOMEN UNDER SIEGE. THE SHAKESPEAREAN ETHICS OF VIOLENCE
}

\author{
DANA PERCEC and ANDREEA ŞERBAN \\ West University of Timișoara \\ 4, Pârvan Blvd, Timișoara, Romania \\ danachetri@email.com \\ anyon1981@yahoo.com
}

\begin{abstract}
This paper discusses notions of physical violence, domestic violence, and sexual assault and the ways in which these were socially and legally perceived in early modern Europe. Special attention will be paid to a number of Shakespearean plays, such as Titus Andronicus and Edward III, but also to the narrative poem The Rape of Lucrece (whose motifs were later adopted in Cymbeline), where the consumption of the female body as a work of art is combined with verbal and physical abuse.
\end{abstract}

Key words: consumption, rape, sexual assault, siege, violence

\section{Introduction}

The fourth act of William Shakespeare's Titus Andronicus opens with the raped and mutilated Lavinia chasing Lucius' son, gesturing at the book in the boy's hand, Ovid's Metamorphoses. She manages to turn the pages to the story of the rape of Philomela, thus informing her father and uncle about Tamora's sons' deeds. Starting from this scene, which is one of Ovid's most prominent influences on Shakespeare's plays, the paper will discuss notions of physical violence, domestic violence and sexual assault and the way in which they are socially and legally perceived in premodern and early modern Europe. Special attention will be paid to such Shakespearean plays as Titus Andronicus and Edward III, probably the best example of sexual harassment in early modern fiction, but also to the narrative poem The Rape of Lucrece (whose motifs were later adopted in 
Cymbeline), where the consumption of the female body as a work of art is combined with verbal and physical abuse. In analysing the male-female relations in these plays, the paper makes use of a series of gender metaphors: the "not-quite-dead-body" (Aebischer 2004:6), the evacuated body (Bronfen 1992:45), the besieged body, the obscene and obscene body (Nead 1992:25), where the body, consumed as a work of art, is an artistic and contained one, while the aggressed body, open and leaking, is a sign of excess and an incentive to aggressive action.

\section{The siege as a gendered notion}

The potentially double role of silence is also illustrated by a play such as Titus Andronicus, in which Lavinia's enforced muteness is, for men, both a requirement and a disquieting condition. In The History of Sexuality (1995:27), Foucault argued that silence is not just the absolute limit of discourse, but also an element that functions alongside the things said, in relation to them. We must try to determine the different ways of not saying things, which type of discourse or which form of discretion is authorised in particular situations: there is not one silence, but many. Emily Detmer-Goebel (2001:75) notices that Lavinia's silence is not only brutally oppressive (from the point of view of the rapists), but also troubling (from the point of view of the men in her own family). In this sense, both speaking and silence can be threatening. If she could speak, her testimony would endanger the criminals' freedom and life. The fact that she can't speak prevents her father from avenging his stained honour. Men depend on the young woman's ability and willingness to 'tell' about the rape. As Detmer-Goebel puts it (2001:76), "Titus Andronicus dramatically registers the culture's anxiety over men's increased dependence on women's voices and, in doing so, shapes and sustains early modern England's contradictory attitude toward a woman's accusation of rape".

Lavinia's body is, in John Hunt's formulation about Hamlet, "catastrophic" (1988:27). Hunt explains his choice of the epithet: "The human body in Hamlet forms human experience, being the medium through which men suffer and act. But the body also deforms human beings and threatens ultimately to reduce them to nothing. The nonbeing lurking at the material center of being announces itself everywhere in the play's corporeal imagery, and occupies Hamlet's mind as he tries to find his way from the regal 
death that initiates the action to the regal death that concludes it". Likewise, we may argue that Lavinia's mutilated body, and later her corpse, mediate her family's living experience and also deform their humanity (especially in Titus' case).

Lavinia's silence, unlike Kate's in The Taming of the Shrew, brings up more than just the issue of an oppressive gendered ideal of feminine decorum. Disclosing rape has a different impact from that of revealing the results of a domestic argument. Shakespeare does illustrate the fact that Lavinia's 'talking' cannot do her much good - in a way similar to Kate's problem - when he has her plead with the rapists in the 'wrong' way. She denies their masculinity by evoking images of nursing: "The milk thou suck'st from her did turn to marble;/Even at thy teat thou hadst thy tyranny." (II, 3)

The metaphorical argumentation is similar, in a way, to that of Lady Macbeth, who evokes images of sucking babes to deny her own femininity. But, in the critical situation Lavinia finds herself in, her talk is excessive because it lacks eloquence. After the mutilation, however, Lavinia does become eloquent: she persuades through the pathos of her body language, her "martyred signs" (III, 2). She becomes a discursive body - with the term used elsewhere (Percec 2006:211) to characterise Hippolyta's meaningful absence in A Midsummer Night's Dream or the marginality of the figure of the Amazon in literature. Lavinia's verbal silence helps her more than her ability to talk. Her voice is, however, potentially powerful. The rapists cut out her tongue (and not her nose, for instance - a quite common form of mutilation in times of war) not (only) to disfigure and humiliate her, but (also) out of a desperate need to silence her. After she is silenced, the rapists, relieved, mock her disability. It is true that, even before the mutilation, Lavinia is unable to talk about the rape - in this case, a moral inability - when she entreats Tamora to kill her rather than to leave her in Demetrius's and Chiron's hands:

Tis present death I beg; and one thing more

Than womanhood denies my tongue to tell:

$\mathrm{O}$, keep me from their worse than killing lust,

And tumble me into some loathsome pit,

Where never man's eye may behold my body: (II, 3) 
If the rapists need Lavinia's silence, her family needs her voice. However, as Emily Detmer-Goebel (2001:81) points out, this need is eclipsed by the way Marcus and Titus repeatedly ignore Lavinia's attempts to 'tell' about the criminals. Although Marcus immediately evokes mythological images of rape when he sees Lavinia in the forest ("But sure some Tereus hath deflowered thee,/ And lest thou shouldst detect him, cut thy tongue", II, 4), this clairvoyance disappears very soon. When Lavinia points to Ovid's Metamorphoses in the library, Marcus has already forgotten his Ovidian exclamations of some time ago. He is also shocked when Lavinia finally scratches the Latin word for rape in the sand. Titus also proves to be familiar with Ovid's story only after Lavinia's scratching of words in the sand: "Lavinia, wert thou thus surprised, sweet girl?/ Ravished and wronged, as Philomela was?" (IV, 1), and not when she shows him the Latin poet's book. Because Lavinia is unable to speak or write, both Titus and Marcus give up asking her questions very soon after the mutilation. This illustrates the fact that the recognition of women as a source of knowledge is underrated in a patriarchal society. She is not unable to communicate (as we find out from her repeated attempts to 'tell'), yet it is true that her willingness to 'tell' is undermined by her shame. When Marcus first refers to the Ovidian rape scene, it would, perhaps, have been enough for Lavinia to nod. But, just as she can't name rape in front of a woman, she can't admit having been raped in front of a man ("Yet do thy cheeks look red", notices Marcus in II, 4). Blushing is not revealing to Marcus: he can't, or doesn't bother to, read nonverbal signs on Lavinia's martyred body. The raped woman, unable to nod when asked directly, is a typical representative of a culture that prescribes silence to women in all embarrassing situations. Her cultural disability only prolongs Lavinia's torments (Scarry 1985:27).

Titus repeatedly tries to understand Lavinia (he compares her to a text or a painting several times), but it is his prejudices that prevent him from being successful. For Titus and Marcus, Lavinia cannot be a source of knowledge. And, in fact, the woman depends on the men's ability and willingness to 'read' her. Titus is too confident about his own ability to interpret what Lavinia 'tells' him to actually pay attention to her:

Hark, Marcus, what she says -

I can interpret all her martyred signs -

She says she drinks no other drink but tears, 
Brewed with her sorrow, mashed upon her cheeks.

Speechless complainer, I will learn thy thought; (III, 2)

Just as Marcus promises to "speak for thee" (II, 4) and then ignores the body language crucial for a proper translation, Titus boasts about how perfect he will be in knowing the meaning of Lavinia's 'dumb action', annihilating her as a reliable source. Through the two poor interpreters, the play emphasises men's anxiety about being dependent on women's authority, on information from them. When Lavinia has finally announced the crime and the criminals, Titus and Marcus completely forget about her. Instead of trying to comfort her, they order her to kneel for the solemn moment of swearing revenge, being more preoccupied with their own honour than hers, with the consequences of their own deeds (killing the rapists) rather than the consequences of the rapists' deeds (Lavinia's suffering and shame).

By comparison, Shakespeare's comedies deal with the theme of violence in a more covert manner. A Midsummer Night's Dream is considered - probably also because of the implications in the title - the closest to a fairy tale, to the world of magic, a play about love as imagination, about creative relationships between humans. However, this first impression may be altered on a closer reading of Duke Theseus's declaration of love: "Hippolyta, I wooed thee with my sword, /And won thy love doing thee injuries (I, 1). 'Winning love' is a common courtship trope, being found in texts that rehabilitate, in a way, the image of woman, so unfavourable in pre-modern Europe. It appears in the tradition of the so-called amour courtois, which places the woman - provided she is loved - on a higher position than the man - provided he is hopelessly in love. Love, in the minstrels' literature, installs a relationship of dependence similar to that between a lord and a vassal, between the knight and the lady. In this context only (except for the religious cult of the Virgin) does the woman become a model of all virtues and respected more than anything else. But 'sword' and 'injuries' - the instrument of violence and its visible consequences - are not part of the tradition of courtly love. Although the forest around Athens where most of the action takes place is completely imaginary, the mythological reference of the play remains valid: Theseus' taking the defeated queen of the Amazons as a prisoner and then forcing her into marriage as a cruel symbol of his 
victory. The 'injuries' suggest that, in this battle, it was not only the ordinary soldiers who became war casualties, and that Hippolyta surrendered only after she was herself wounded. The Duke's courtship speech is similar to what Proteus tells helpless Sylvia when he finds her alone in the woods, in The Two Gentlemen of Verona: "Nay, if the gentle spirit of moving words/ Can no way change you to a milder form,/I'll woo you like a soldier, at arms' end,/And love you 'gainst the nature of love, - force ye." (V, 4), where a rapist's intentions are hidden behind the metaphorical excuse of "wooing" but aggression is not absent at the discursive level because of the implications given by the "soldierly" type of treatment. The paradoxical connection between love and violence suggested by Theseus in A Midsummer Night's Dream is enhanced by Helena's comparison of the ideal relationship between herself and Demetrius with that between a spaniel and an authoritarian, even cruel master: "Use me but as your spaniel: spurn me, strike me,/ Neglect me, lose me; only give me leave,/ Unworthy as I am, to follow you (II, 1).

If there is uncertainty regarding the true attitude behind Hippolyta's silence or about the way in which Kate really sees her marriage at the end of The Taming of the Shrew, when she tells the other women that "Thy husband is thy lord, thy life, thy keeper" and that wives should "place their hands below your husband's foot" $(\mathrm{V}, 5)$, there cannot be any doubt about Helena's masochistic acceptance of Demetrius' brutality and boorishness. (We see, again, correspondences here between images of violence such as that evoked by dog imagery or Kate's placing fingers under men's shoes and those explicitly depicted by Anne in Thomas Heywood's A Woman Killed with Kindness). In Othello, when Desdemona suffers, with a similar masochism, her husband's fury, jealousy, and abuse, Emilia suggests an alternative attitude for women - that of secretly cheating on a husband as the only chance of asserting their rights and obtaining if not justice at least compensation in an epoch when divorce was inconceivable:

Why, we have galls; and though we have some grace,

Yet have we some revenge. Let husbands know

Their wives have sense like them: they see, and smell,

And have their palates both for sweet and sour,

As husbands have. [...] 
Then let them use us well: else let them know,

The ills we do, their ills instruct us so. (IV, 3)

Desdemona's misfortune is that Othello is, above all else, a soldier. Despite traditional criticism that has always presented Othello as a primarily noble character (Bradley 1970), his aggressiveness in the domestic sphere turns him into an uncouth man. From the very beginning of the play, his military career affects his love life, then his marriage. First, this happens in a positive way, as it is the Moor's very prowess on the battlefield that attracts the fair Venetian lady, accustomed to sweeter, but less spectacular talk. Then, Othello admits that his military duty makes their wedding bed one of steel when he asks her to accompany him to Cyprus. However, Desdemona proves very little affected both by this martial setting for their honeymoon and by the events that she has to face immediately after leaving her home and starting to adapt to a rougher life - the storm and the Turks that make their voyage difficult, the drunkards' roistering that wakes her on her first night in Cyprus (II, 3). Othello's problem is not that Desdemona is not 'military' enough: she understands her husband's duties and she also takes all these inconveniences much less dramatically than, perhaps, other women of her rank and breeding would have done. When the Turkish fleet is destroyed (without Othello's military intervention), the Moor is almost left out of work. Since he can no longer prove his manhood on the battlefield or, in general, in the public sphere, he grows uneasy about his private life. Iago, indeed, will characterise Othello's fits of jealousy as "unsuiting such a man" (IV, 1), that is, unsoldierly. As the security of his military identity has crumbled, Othello feels desperate that his identity as a lover and husband may go in the same downward direction. The violent drives - typical, the racial clichés go, of Muslim men - which the black general used to unleash on the battlefield will be aimed now at the person who accepted Othello's military fate with complete devotion and will destroy both the victimiser and his docile victim.

War, if not directly connected to the characters, is often a background to the comedies, suggesting, just as in the case of A Midsummer Night's Dream, a potentially violent or offending attitude men may develop towards women (Dash 1997). In All's Well That Ends Well, Bertram finds an excuse for abandoning his bride by joining in a war in 
Italy as a mercenary. Much Ado about Nothing starts with the return of the victorious army led by Don Pedro to Messina. Claudio and Benedick, the lovers in this comedy, are two of these victorious soldiers. The latter compares his friend's former enthusiasm at the sight of a war scene with his current thrill at the thought of his beloved: "I have known where he would have walked ten mile a-foot to see a good armour; and now he will lie ten nights awake carving the fashion of a new doublet" (II, 3). This is to say that a hardened soldier cannot but help having his life permanently influenced by the experience of the battlefield. The way Claudio will treat his bride has everything to do with the hardiness the ideal soldier has to display in all the events of his life.

Even Petruchio in The Taming of the Shrew proves to have experienced war when he compares the artillery "thunder in the skies", "loud alarums, neighing steeds, and trumpets' clang” (I, 2) to Kate's 'tongue'. The men who have been rejected by Kate are, for Petruchio, only 'boys', cowards who don't know that a woman has to be treated like a battlefield on which there can be only winners and losers after a brutal combat. Fierceness is the best quality of an efficient warrior and he should not give it up even in his private life - a piece of advice that Castiglione gives noblemen, unlike Shakespeare's Henry V who, before the siege of Harfleur, makes a distinction between manly domestic qualities ("modesty") and martial ones (a "tiger's" conduct). Claudio in Much Ado about Nothing makes no such distinction by preserving the tiger's cruelty when he humiliates and abandons a down-hearted bride on the day of their wedding without even caring if she is still alive or has been killed by the shock. Just like Othello, Claudio starts suffering for Hero's death only when he finds out that she had not flirted with men from the window of her room on the night before their wedding. In Hero's silence and obedience, as in that of Bianca, Kate's 'good' sister everybody wants to marry, or that of Hermione, Leontes's virtuous and faithful wife in Winter's Tale, we can immediately identify the potential victim. Faced with the 'tiger', these women have the spirits of a defeated army, of a fortress surrendering after a long and bloody siege. In Titus Andronicus, Aaron urges Tamora's sons to rape Lavinia in a metaphorical discourse that translates this crime into a hunt, as harmless as Orsino's romantic speech about hunting the hart in the opening scene of Twelfth Night. However, Aaron's presentation of the stratagem emphasises the word force: "Single you thither, then, this dainty doe,/And strike her home by force, if not by 
words:" (II, 2). The invitation to strike the hunted animal as an instruction for rape belongs to the same imagery as wooing a woman like a soldier. Men exert power over women in actions specific to their gender: fighting and hunting. The arithmetic of this strategy is simple, the equation being summed up by Demetrius in the same scene: "She is a woman, therefore may be woo' $\mathrm{d}$;/She is a woman, therefore may be won;/She is Lavinia, therefore must be loved.” (II, 1)

In a soldier's world, love is as compulsory as fighting, the very fact that the object of desire is a woman being enough to justify the tiger's conduct. Conquering a woman is not a metaphor; it is the physical translation of conquering a city or an army: by attacking, injuring, besieging, and annihilating the target. The metaphor of wooing as besieging is very powerful in Edward III, where it takes the form of both combined, as a social and political comment. The King wants to force the Countess of Salisbury to become his mistress just as he is forcing France to accept English supremacy. The armed invasion, the numerous casualties of the Hundred Years' War, increase the violent connotations of Edward's courtship. He forces the lady to swear she will obey him before she knows what he really wants. When she realises that his claim has sexual implications, she announces she will give the King her life together with the beauty of her body, her sacrifice - an indirect threat to commit suicide which is subtle enough not to voice clearly her refusal to keep her oath. The Countess's presentation of her rejection as readiness to die for the King can be compared with the token of loyalty a soldier offers his king when he dies on the battlefield, the gesture thus containing an inherent ambiguity as to the warrior's most intimate feelings (fear, disapproval of war, doubts about the leader's true intentions, etc., best illustrated by Falstaff in Henry IV and by the English soldiers at Agincourt in Henry V).

The Countess's comment on Edward's attempted rape as an "unnatural besiege" (II, 2) reflects both her disapproval of brutality in a man's relationship with a woman and a more general discontent with martial politics and with the heavy loss of human life they have as a consequence. The relationship, invested with great symbolic power, between a lord and a vassal is massively played upon here. According to Foucault (1995), docility and discipline is different from vassalage, as the former is concerned with the operations of the body, whereas the latter has to do with ritual signs of subjection, the product of the 
body's operations, and is performed from a distance. In the Countess's case, however, docility and vassalage seem to coincide, as both the King and the noble lady use a specific code and are tributary to a specific mentality, while manipulating each other in a more subtle way, supervising each other very closely.

In The Romance of the Rose, before the scene in which the jealous husband takes his innocent wife by the hair and drags her around the house, Jean de Meun contrasts the idyllic, simple life of the Golden Age when people lived without the tyranny of institutions (including royalty, army and marriage) with the age of "seigniory", of knighthood and of battles for royal claims when "High rule sets equal love aside" for "Never can love and seigniory / Travel together" (Vol. Two, C. XLVII, 8866, 8863-4). Theseus, Claudio, Bertram and Leontes are all seigniors or the King's soldiers, and their symptoms of chronic violence are immediately identifiable in Jean de Meun's descriptors. Henry V's call for equilibrium in his urging his soldiers to preserve a double nature (a "tiger's" conduct in war and "modesty" at home) remains a mere desideratum.

\section{The erased body}

Two plays that are more loosely focused on the treatment of the female body are Hamlet and King Lear. In the former, the woman's body is a vanishing body: object and improper property (Aebischer 2004), connoting instability, elusiveness, promiscuity, and ambiguity. Ophelia's deranged body and mind are presented as disruptions of the body politic. The dead female body is idealized and poetic (as shown in Gertrude's speech at Ophelia's funeral), in sheer contrast with the "regular" corpse, grotesque and decomposing (as shown in the gravediggers' scene, with Hamlet's casual disposal of Yorick's skull in the grave). Secondly, Gertrude's very presence in the play works as a sexual and political reminder ("None wed the second but who kill'd the first" III, 2), since the possession of the queen's body equals the possession of the crown. This is why the expected identification between the Player Queen and Gertrude is so crucial to Hamlet: it works as a coercion into complicity with the male-authored, male-played action. "If she should break it now" (III, 2), Hamlet muses, but Gertrude does not break, accepting the convention but being determined to remain detached, refusing to play the guilty part by identifying with the male - Claudius and the actor. "The Lady doth protest 
too much, methinks" (III, 2), she says, making herself an aesthetic and distanced member of the audience of the mousetrap, like Polonius, but unlike the empathic and involved response of Hamlet and Claudius.

In King Lear, the female characters are rudely marginalised (so little is known of Lear's daughters and their relationship with their father that their biography leaves room for endless speculation: "in need of Valium, psychoanalysis, or both," Gay 1994:177). The daughters' bodies, just like Kent's and Gloucester's, are instrumentalised only so as to amplify Lear's suffering. Thus, the play inflicts suffering both on the guilty and on the innocent, on the people involved and on the spectators. The relationship between body and speech is more conspicuous here than elsewhere: Lear has an absolute belief in the power of words, as shown in the opening scene, when he is ready to offer his daughters fortunes according to how much they claim to love him. This, combined with Cordelia's refusal to join the game and her "nothing"ness, leads to a loss of linguistic (and literal) power. Goneril and Regan usurp Lear's throne, as they usurp his power to use speech. Cordelia's initial "nothing"ness remains constant to the very end of the play, when she offers no more than a silent, unreadable body, unresponsive in her death as she seemed to be in her life: "Lend me a looking-glass;/If that her breath will mist or stain the stone,/Why, then she lives.[...] Cordelia, Cordelia! stay a little. Ha!/What is't thou say'st? Her voice was ever soft,/Gentle, and low, an excellent thing in woman. [...] Do you see this? Look on her, look, her lips,/Look there, look there! Dies.” (V, 3). Her body is a terminus, after which no restoration of a state of language is possible: "And thou no breath at all? Thou'lt come no more,/Never, never, never, never, never!” (V, 3).

\section{The body as work of art}

The Rape of Lucrece draws on the story described in both Ovid's Fasti and Livy's history of Rome. In 509 BC, Sextus Tarquinius, son of Tarquin, the king of Rome, raped Lucretia (Lucrece), wife of Collatinus, one of the king's aristocratic retainers. As a result, Lucrece committed suicide. Her body was paraded in the Roman Forum by the king's nephew, inciting a full-scale revolt against the Tarquins led by Lucius Junius Brutus, the banishment of the royal family, and the founding of the Roman republic. Ovid's poem is an extensive treatment of the official Roman calendar or Fasti, loosely imitating Hesiod's 
Works and Days, each book of which discusses one month of the Roman calendar.. In addition to some brief astronomical notes, its more significant portions look at the Roman religious festivals, the rites performed at them, and their mythological explanations. These explanations preserve much mythological and religious lore that would otherwise have been lost. Shakespeare retains the essence of the classical story, adding that Tarquin's lust for Lucrece is the result of her own husband's praise of her. Shakespeare later used the same idea in his late romance Cymbeline (circa 1609-1610). In this play, Iachimo bets Posthumus (the husband) that he can make Imogen commit adultery with him. Even though he does not succeed, he is able to convince Posthumus he has done so by using information about Imogen's bedchamber and body. Iachiamo hides in a trunk which is delivered to Imogen's chamber under the pretence of safeguarding some jewels, a gift for her father King Cymbeline. The scene in which he emerges from the trunk (II, 2) mimics the scene in The Rape of Lucrece. Indeed, Iachimo compares himself to Tarquin in the scene: "Our Tarquin thus, / Did softly press the rushes ere he waken'd / The chastity he wounded" (II, 2, 12-14). Lucrece is described as a work of art, objectified as if she were a material possession. Tarquin's rape is described in terms of besieging, with the man conquering the maiden's physical attributes. Although Lucrece is raped, the poem offers an apology to absolve her of guilt (lines 1240-46). Like Shakespeare's other raped women, Lucrece gains symbolic value: through her suicide, her body metamorphoses into a political symbol. The woman's political body is threatened by the man's natural inclination towards physical violence: the rape is presented as mutilation of Lucrece's flesh, while Tarquin's sex is a dagger or sword piercing through Lucrece's flesh. The political metaphor continues when the incident is evoked in the descriptive language of military campaigns, drawing on the violence of attacks: Tarquin's sexual impulses are equated with the spirit of a soldier marching on his foe ("By reprobate desire so madly led / The Roman lord marcheth to Lucrece' bed", 300-301); he threatens the young woman with his sword. The poem's rhetorical nature strengthens the notion of the woman's body as a work of art. The materiality of the language disrupts a rhetorical tradition oriented towards the pure idealisation of the victim and a legal tradition, and social practice, which keeps silent about rape narratives. Lucrece's own rhetorical eloquence proves that the victim seeks out a more active, violent retribution on the rapist 
and on the monarchical regime that he represents (even if the active revenge must be carried out by a male agent - Brutus).

Shakespeare's late play, Cymbeline, transforms the seduction scene into the inventory of the woman's body and bedchamber (a décor set for passion): statues of silver Cupids (as a sexual innuendo); hangings depicting Diana bathing and Cleopatra's first encounter with Antony (Diana is a chaste presence; in accordance with Imogen's good faith; Cleopatra is the embodiment of illegal love and sexuality, while Venus, passionate, seductive, and dangerous, offers an analogy between the Queen of Egypt, greeting her imperial Roman guest, and Imogen welcoming her Roman visitor in her intimacy). According to Catherine Belsey (1999:123): “Iachimo's account of the furnishings is surprisingly specific in a play which elsewhere depends on a broad generic distinction between court and countryside, punctuated by brief excursions into an equally stereotypical Machiavellian Italy". Thus, the function of the interior decorations is to enhance the credulity of Iachimo's version and to guarantee, through their symbolism, the sexual connotation of the seducer's boastfulness. In this version, Imogen's actual betrayal is of less importance than the face the husband loses in a man-to-man confrontation (symbolic or not) - Posthumus in confrontation with a man with whom he made a bet (therefore a commitment).

\section{Conclusions}

A major aspect of such plays as those mentioned above is the theatre's potential to reflect violence. They prove that tragedy not only represents an assault on the body but is also violent in its effect on the spectator, forcing a response from viewers, as well as from characters. Major motifs, such as guilt and victimisation, are embodied by characters who are rape survivors, harassed and neglected women, wives of victimisers. These characters are physical and discursive bodies: women using language to report, accuse, and avenge, women using language to claim attention or to negotiate it, men using language to perform actions upon more or less passive recipients, etc. Visualising bodies in pain (the mutilated body, the corpse, etc.) is an important part of the cultural history of their reception on the early modern stage. 


\section{References}

Aebischer, P. 2004. Shakespeare's Violated Bodies. Stage and Screen Performance. Cambridge: Cambridge University Press.

Belsey, C. 1999. Shakespeare and the Loss of Eden. London: Palgrave Macmillan.

Bevington, D. (ed.) 2003. Shakespeare's Comedies. New York, London: Pearson Longman.

Bevington, D. (ed.) 2003. Shakespeare's Sonnets and Poems. New York, London: Pearson Longman.

Bevington, D. (ed.) 2003. Shakespeare's Tragedies. New York, London: Pearson Longman.

Bradley, A.C. 1970. Shakespearean Tragedy. London: Macmillan.

Bronfen, E. 1992. Over Her Dead Body: Death, Femininity and the Aesthetic. Manchester: Manchester University Press.

Dash, I.G. 1997. Women's Worlds in Shakespeare's Plays. London: Associated Universities.

Detmer-Goebel, E. 2001. "The Need for Lavinia's Voice: Titus Andronicus and the Telling of Rape" in C. Barroll (ed.). Shakespeare Studies. London: Associated University Press, vol. XXIX.

Foucault, M. 1995. Istoria sexualităţii. Timişoara: Editura de Vest.

Gay, P. 1994. As She Likes It: Shakespeare's Unruly Women. London and New York: Routledge.

Hunt, J. 1988. "A Thing of Nothing: The Catastrophic Body in Hamlet” in Shakespeare

Quarterly, 39, 1.

Meun, J. de. 1999. The Romance of the Rose. New York: Oxford World's Classics.

Nead, L. 1992. The Female Nude: Art, Obscenity and Sexuality. London and New York: Routledge.

Percec, D. The Body's Tale. Some Ado about Shakespeare's Plays. Timişoara: Editura Universităţii de Vest.

Scarry, E. 1985. The Body in Pain: The Making and Unmaking of the World. Oxford: Oxford University Press. 